\title{
Teamwork in the Family Health Strategy: professionals' perceptions
}

\author{
Trabalho em equipe na Estratégia Saúde da Família: percepções dos profissionais \\ Trabajo en equipo en la Estrategia de Salud Familiar: percepciones de los profesionales
}

\author{
Pedro Cesar Condeles ${ }^{1}(1)$ \\ Carolina Feliciana Bracarense ${ }^{1}$ (D) \\ Bibiane Dias Miranda Parreira ${ }^{1}(1)$ \\ Marina Pereira Rezende ${ }^{1}$ (C) \\ Lucieli Dias Pedreschi Chaves ${ }^{2}$ (10 \\ Bethania Ferreira Goulart ${ }^{1}[$ C
}

${ }^{1}$ Curso de Enfermagem. Universidade Federal do Triângulo Mineiro. Uberaba, MG. Brasil. ${ }^{2}$ Escola de Enfermagem de Ribeirão Preto. Universidade de São Paulo. Ribeirão Preto, SP. Brasil.

\begin{abstract}
Objective: to identify the perceptions of health professionals about teamwork in the Family Health Strategy. Methods: descriptive study / qualitative approach, carried out with a Family Health Strategy team. Semi-structured interviews were conducted with eight professionals. Data collection took place in 2017. Thematic modality/ content analysis was used for data treatment. Results: in the analysis of the data emerged three thematic categories: Constituent elements of the teamwork: contemplates important attributes for construction of teamwork, such as dialogue / collaboration / help / consensus and union; Professional specificity: it shows the accomplishment of the work based on the specificity of each profession; Teamwork at specific times: it reveals that, for the interviewees, teamwork occurs in defined moments, as in the circumstances of group attendance, in lectures and in continuing education. Conclusion and Implications for practice: Professionals perceive teamwork as one that is anchored in mutual aid, collaboration and common goals. However, in practice, the work follows the trend more individualized. Evidence of possible changes to be implemented in daily life, in order to promote the modality of teamwork, with a view to integral assistance.
\end{abstract}

Keywords: Cooperative Behavior; Primary Health Care; Family Health Strategy.

\section{Resumo}

Objetivo: identificar as percepções dos profissionais de saúde a respeito de trabalho em equipe na Estratégia Saúde da Família. Métodos: estudo descritivo/abordagem qualitativa, realizado com uma equipe de Estratégia Saúde da Família. Foram realizadas entrevistas semiestruturadas com oito profissionais. Coleta de dados ocorreu em 2017. Para tratamento dos dados, utilizou-se análise de conteúdo/modalidade temática. Resultados: na análise dos dados emergiram três categorias temáticas: Elementos constitutivos do trabalho em equipe: contempla atributos importantes para construção do trabalho em equipe, como diálogo/ colaboração/auxílio/consenso e união; Especificidade profissional: evidencia a realização do trabalho pautado na especificidade de cada profissão; Trabalho em equipe em momentos específicos: desvela que, para os entrevistados, o trabalho em equipe ocorre em momentos definidos, como nas circunstâncias de atendimento em grupo, em palestras e na educação continuada. Conclusão e implicações para prática: Os profissionais percebem o trabalho em equipe como aquele ancorado na ajuda mútua, colaboração e nos objetivos comuns. No entanto, na prática, o trabalho segue a tendência mais individualizada. É preciso cunhar mudanças possiveis de serem implementadas no cotidiano, de modo a promover a modalidade do trabalho em equipe, com vistas à assistência integral.

Palavras-chave: Comportamento Cooperativo; Atenção Primária à Saúde; Estratégia Saúde da Família.

\section{REsumen}

Objetivo: identificar las percepciones de los profesionales de la salud respecto al trabajo en equipo en la Estrategia de Salud Familiar. Métodos: estudio descriptivo/abordaje cualitativo, realizado con un equipo de Estrategia de Salud Familiar. Se realizaron entrevistas semiestructuradas con ocho profesionales. La recolección de datos ocurrió en 2017. Para el tratamiento de los datos se utilizó el análisis de contenido/modalidad temática. Resultados: en el análisis de los datos surgieron tres categorías temáticas: Elementos constitutivos del trabajo en equipo: contempla atributos importantes para la construcción del trabajo en equipo, como diálogo/colaboración/ayuda/consenso y unión; Especificidad profesional: evidencia la realización del trabajo pautado en la especificidad de cada profesión; Trabajo en equipo en momentos específicos: desvela que, para los entrevistados, el trabajo en equipo ocurre en momentos definidos, como en las circunstancias de atención en grupo, en conferencias y en la educación continuada. Conclusión e implicaciones para la práctica: los resultados demuestran que los profesionales perciben el trabajo en equipo como anclado en la ayuda mutua, la colaboración y los objetivos comunes. Sin embargo, en la práctica, el trabajo sigue la tendencia más individualizada. Es necesario evidenciar posibles cambios de ser implementados en el cotidiano, de modo a promover la modalidad del trabajo en equipo, con miras a una asistencia integral.

Palabras clave: Conducta Cooperativa; Atención Primaria de la Salud; Estrategia de Salud Familiar. 


\section{INTRODUCTION}

Since the 1960s, discussions have emerged on the importance of Primary Health Care (PHC) in the world. The Alma Ata statement (1978) and the Ottawa Charter (1986) displayed the theme and contemplated tools and proposals for its implementation. In this perspective, strategies for developing health anchored in the structures of the social formations, supported by health professionals, were elaborated in local health units, responsible for the greater part of care. ${ }^{1-3}$ This represented an attempt to overcome the predominant health care model, marked by the paradigm of disease and fragmentation, to the detriment of integrality.

Following the world trend, Brazil, in 1994, instituted the Family Health Program (FHP) and in 2009 took as its model the Family Health Strategy (FHS) within the scope of the Unified Health System (Sistema Único de Saúde, SUS), to reorganize basic care, following SUS guidelines, integrating the Health Care Networks ( $\mathrm{HCN}) \cdot{ }^{4-6}$ It is worth noting that the $\mathrm{HCN}$ aim to provide integral care, with articulation between services, actions and professionals. This also seeks to be consistent with the population's health needs, to overcome care fragmentation, to expand access to health services, and to ensure equity and universality. ${ }^{4-5,7-8}$

In this sense, the National Policy of Basic Care recommends that the FHS should be composed of a minimal team of professionals, among them, a doctor, a nurse, a nursing assistant or a nursing technician, community health agents and oral health professionals may still be added. As assignments, the team should provide integral, continuous and organized care to the attached population, through interprofessional and team work, integrating technical and professional areas with different qualifications. ${ }^{9-10}$

It is worth noting that the proposal of the FHS is in line with the modality of team integration, since it advocates collective work, articulation of actions and knowledge, effective communicative interaction for the agents, and flexibility in labor division. ${ }^{11}$

However, it is observed that daily life is still marked by the predominance of teams where the agents perform a fragmented work, little articulated and sustained by impoverished communication processes. This leads to segmented and piecemeal work, which may compromise the patient's full care. ${ }^{12-13}$ In this perspective, the context of health services is closer to that of team grouping, ${ }^{11}$ since it does not promote articulated, integrated and dialogical labor.

This may be a reflection related to the influence of the Taylorist-Fordist fragmentation that stimulates and reinforces the rigidity in the division of tasks, which culminates with the distancing of the health team members, compromising integral care for the users. ${ }^{12,14}$ In addition, it can be seen that the curricular structure of undergraduate courses in health does not promote interprofessional practice, since training still follows the highly specialized, technical and individualistic approach, which does not favor a shared performance. ${ }^{15-18}$
To consolidate interprofessional teamwork, substantial elements are needed to qualify it as a powerful tool for coping with health work fragmentation. These elements include interprofessional cooperation/collaboration, communication, mutual respect, exchange of knowledge, articulation of common actions and objectives. ${ }^{15,19,20}$ Given such condition, teamwork, when carried out following the principles of articulation and integration among agents, knowledge and actions, with emphasis on care integrality, can represent an important mechanism to enable the FHS as a policy to reorganize the $\mathrm{FHC}$.

Although scientific production evidences teamwork as a strategy to overcome fragmentation in health, this is still not enough to transform the daily practice and the way of working in health. Not even the political proposal of the FHS, which values the work done through integrated teams represents a path that is being followed in practice. The logic that guides the health scenario is cut by the division into professional categories and the low articulation in the work process.

The work process is understood as the way in which the professionals perform their daily tasks. Without detailing, it is the grouping of actions developed by men, through the means of production and in relation to some object, with the purpose of promoting modifications and making it fruitful. Thus, the work process consists of the agents, the production means, the objects and the objectives/purposes. So that the less organized the work process is, the most arduous will it be to provoke reflections and act on it, ${ }^{21}$ a situation that is found in the APS and FHS.

Considering the FHS, it should be noted that the fact that the professionals work in the same place and take care of the same population does not guarantee teamwork accomplishment. ${ }^{11}$ Teamwork goes far beyond mere physical proximity, it represents a collective work modality built up by the technical articulation and interaction among the work process agents, their knowledge and practices.

Given the aforementioned, what is the professionals' understanding about teamwork in the FHS is questioned. It is believed that analyzing perceptions can favor the production of actions that enable the signaling on changes to be implemented, both in the daily work as well as in the academic qualification and in service, in order to raise awareness, promote and make teamwork feasible, understood as a powerful health technology. This study aimed to identify the perceptions of health professionals regarding teamwork in the Family Health Strategy.

\section{METHODOLOGY}

This is a descriptive study with a qualitative approach, performed with an FHS team from a municipality in the inland of Minas Gerais. This municipality counts on an estimated population of 300,000 people ${ }^{22}$ and has its health system divided into three Sanitary Districts with 20 urban FHS teams and one rural in Sanitary District I; twelve urban and two rural FHS teams in Sanitary District II and 15 urban FHS teams and one rural in Sanitary District III. 
In order to take part in the research, the Family Health team of Sanitary District II was selected, which included the largest attached population, which had 3,714 cared people, at data collect time. The team consisted of five Community Health Agents (CHA), an oral health assistant, a dentist, a nurse, a physician, and a nursing technician.

Of the total of 10 professionals in the team, eight professionals participated that met the inclusion criteria, which consisted in acting in the said FHT for at least six months. Those who were away from work at the time of data collect and those not located after three attempts to schedule the interview were excluded.

The method used for data collect was the semi-structured interview. The script of the interview was prepared by the authors themselves, submitted to apparent and content validation by three experts in the thematic and/or research methodology. A pilot test was carried out for testing the data collect procedures in real conditions, counting on participants who would not be part of the definitive data collect, which were from another FHS team. The script consisted of two parts: the first one focused on the socio-demographic and professional data of the participants; the second is composed of the following guiding questions: From your professional experience here: Tell me how the professionals do the work here at FHS. Teamwork: What do you understand by that? Based on your understanding, do you consider that the work done here is teamwork? Justify your answer.

For the definitive data collect, the interview was developed by the own researcher, face to face, recorded in a digital media, in a day and place previously scheduled, in agreement among the participants, the people in charge for the service and the researcher, in an environment that ensured privacy. There was no onus for the participants. Data were collected in 2017. To preserve secrecy and anonymity, participants were labeled E1, E2, E3, and so on up to $E 8$, with the letter $E$ being used to represent the participant's interview, and the numeral, the sequential interviewing order. It is pertinent to point out that there was no concern with the identification and distinction for the professional category of the interviewees, because the interest of the study was for the team, in its entirety.

For analyzing the data, the interviews were fully transcribed by the researcher himself and content analysis was used in the thematic modality, with the three following stages. In the first stage, referred to as pre-analysis, we performed an exhaustive reading of the material to capture the whole of the data and the particularities of the set. In the second phase, the material was exploited, in order to identify the categories that emerged and the grouping, by affinity, of the context units. In the last stage, interpretive synthesis, excerpts were grouped according to themes, which emerged from the interviews, and organization was done in thematic units. ${ }^{23}$ Concepts of the health work process were used as theoretical reference. ${ }^{21}$ The elements of the work process (object, purpose, instruments and agents) guided the analysis of the results from the daily perspective and the dynamics of work in the health team.
In compliance with Resolution 466/2012 of the National Health Council, ${ }^{24}$ the project was approved by the Human Research Ethics Committee of Universidade Federal do Triângulo Mineiro, on August 29, 2016, with CAAE 56426916.4.0000.5154 and opinion number: 1.700 .853 . The participants in the research signed the Free and Informed Consent Term (FICT).

\section{RESULTS}

Thus, the study population consisted of eight professionals from the FHS team, of whom, five were community health agents $(62.5 \%)$, a dentist $(12.5 \%)$, a nurse $(12,5 \%)$ and a physician (12.5\%).

Two professionals did not take part, one being the oral health assistant who refused to take part in the interview, and the second one being the nursing technician that was exonerated terminating the contract with the city hall, during the data collect period.

Among the eight participants in the study, all were female; with ages ranging from 29 to 56 years old, the average being 44 years old; four (50\%) professionals had completed higher education, and the other four (50\%) had completed high school. The average qualification time was 22 years, with performance time in the FHS varying from one to 11 years, with a six year performance in average.

The results that emerged from the interviews were grouped, by content affinity, into three thematic categories: Building elements for teamwork, that concentrates the largest number of record units; Professional specificity; and Teamwork at specific times.

The thematic category Constitutive elements of teamwork reveals that the interviewees identify collaboration, dialogue, mutual assistance, consensus and union as attributes for building up and accomplishing teamwork. It may be said that these elements correspond to the means of production used by the agents to modify the condition of the patient in order to promote health and prevent diseases. ${ }^{21}$ This is illustrated in the following statements:

\section{[...] teamwork is when a sole professional cannot solve that problem [...] they need other professionals together to add knowledge [...] experience (E1). \\ [...] I don't have to solve it alone, there you have to talk [...] to see what it is better [...] I see that I need help from another friend community agent, because [...] an experience that she has and that I don't have [...] I talk to her and she helps me $[\ldots]$ (E3). \\ [...] We work as in a group, everyone has a role in the team, and we exchange ideas, information, knowledge, experience, make planning, do continuous education, then we have teamwork [...] (E8).}

Collaboration is evident as an indispensable instrument for accomplishing teamwork given the complexity required for the team's performance in the FHS. The following statement exemplifies this question: 
[...] I think it is essential, primordial [...] we have to have the collaboration of each one so that the work can happen [...] we work in many fronts, it is a job of great complexity [...] (E8).

For the participants, another important aspect concerns the common goals for reaching teamwork. They reveal that for the provision of integral and quality assistance to the population, it is fundamental that all the professionals of the team are aligned with the agreed objectives, as illustrated in the following statements:

[...] teamwork [...] when everyone works for an ideal, not just in numbers of people, but with the same goals (E2).

We carry through together [...] and this generally works very well because it is one helping the other [...] teamwork has to be everyone together for the same purpose [...] (E5).

The second thematic category, Professional specificity, evidences the accomplishment of the work based on the specificity of each profession. It indicates a division of the professionals' work in steps, including "inside" and "outside" the Unit, which can be seen in the following statements:

[...] the nurse has her job here [in the unit] [...] and outside

$[\ldots]$ the dentist too. She has her work here [...] and on the days that she has to go to the nursery and [...] school [...] the community agent must always be together (E4).

Kind like, the community agent acts in the area (...) we have a nurse visiting with an agent. [community], the doctor with the academics also make a visit with an agent [community] in the area, the nursing technician stays more here inside the unit [...] (E6).

[...] each one has their functions [...] the community agents are more in direct contact with the families, usually they bring us the problems that they find [...] (E7).

Some statements indicate the specificity of actions according to professional training, but also reveal a timid attempt to articulate among professionals. According to the analyzed scenario, the agents that develop the work process can be seen under the individual, group and team perspectives, permanently committed to achieving the purpose of the work process, which is health and quality of life for the patients. ${ }^{21}$

[...] the community agent goes to the homes, if she sees something she passes it to the nurse, and then the nurse goes there with us, the doctor has her day [...] (E3).

[...] Teamwork is when all are trying to work together for a better result, and we do what is [our] part [professional capacity] [...] let's assume, any conversation I have with the user at home, in the visit, if it is for the dentist I arrive and will try to pass for her secretary [...] for the nurse it is the same thing [...] in this direction [...] and each one in their square [...] (E4).
The third thematic category, Teamwork at specific times, reveals that for the interviewees, the teamwork strategy occurs in specific situations, such as in the circumstances of group care, in actions with schoolchildren, in lectures and in continuing education. This can be seen in the following statements:

[...] in groups [with users] we work as a team, in continuing education [...] and then in these times we work as a team [...] (E1).

[...] in the groups [with users] we work as a team, when we do our work in school, and then we go there as a team to do evaluation [...] lectures at school [...] (E1).

[...] Usually on Monday we have a visit with the doctor at home, and there are two [community agents] who go with the doctor and the other ones [community agents] go to the school with a dentist, here is a nursery day, there is the day of the hypertensive and diabetic group [...] (E5).

Considering the reports of the participants, it is evident that, according to the perceptions of the professionals from the FHS team, teamwork happens at times of grouping the professionals, related to some specific occasion and defined site, and there may be articulation on the actions of the team agents or not.

\section{DISCUSSION}

It is verified through the reports that the FHS professionals share in their perspectives that teamwork is built up through elements related to the interprofessional practice in health. This was clearly evidenced in the category Constituting elements of teamwork. The presence of the non-material instruments of the work process as an enabler for teamwork was identified in the interviewees' statements. They demonstrate collaboration and mutual aid as crucial attributes for teamwork. ${ }^{19-20}$

These findings reveal that FHS professionals recognize that for integral and collective teamwork, team communication, collaboration and mutual assistance are indispensable, so that each professional with his or her specific training may contribute to the work process of the health team. ${ }^{11,20}$

From the FHS team perspective, collaboration is developed with the purpose of articulating the actions of the various specialties, aiming at integral health care. In this sense, teams that develop the collaborative practice, use it as a mechanism for effective teamwork, information exchange, interdependence, horizontal communication, confidence, help, mutual respect and responsibility among the team's professionals. ${ }^{25-26}$ These elements emerged in the results of this study, which indicates an approximation among the findings and the scientific production.

Trust and respect are two related terms as underlying prerequisites for a successful collaboration. A relationship of trust and respect can create an open and secure environment where the professionals dare to think and act beyond their own discipline. ${ }^{27}$ 
This allows for a creative and expanded performance on the work object, as it allows the professionals to see themselves and act as partners in the search for the purpose of the work process, that is, integrated and collective care.

Such aspects have a narrow bond with the non-material instruments related to the work process. This means that, in the studied context, participants identify these elements as drivers for implementing the teamwork proposal. The way in which the professionals are related with each other and interact directly influences work's dynamics.

Thus, it is emphasized that teamwork must be built up through the interaction and articulation of the professionals in a team, attempting to overcome work fragmentation and, consequently, subdividing healthcare. The work process agents need to have an interprofessional relationship anchored in collaboration, mutual aid and union, attempting to reach the work process purpose, that is, integral and quality assistance to the community attached to the FHT.

Teamwork is effective when there is construction of interprofessionality within the team, so that all professionals use and appropriate elements that enable an integrated team, that the objectives and goals of each professional are aligned in the perspective on a collective work, contributing directly to a broader view on the work's object. ${ }^{14,27-29}$

The thematic category Professional specificity indicates from the perspective of the research participants that the work follows a logic divided by professional categories, that is, each work process agent develops their specific attributions, and they try to articulate with the other professionals.

It is opportune to pointing out that teamwork is not intended to abolish professional specificity, but rather to improve and articulate the specific skills of each profession, favoring collective work, integrating the knowledge on different health action fields. ${ }^{11}$ However, it is questioned if these articulations on the diverse professional formations, in the focused context, are fragile, since they occur in times of legitimate necessity. It is not very clear, through the reports, if the agents perform the work in an articulated and integrated way as a premise to do it in daily and collective health.

In this sense, the technical division of labor depends on the interaction degree where the health team members are involved, and can be molded into team integration or grouping. ${ }^{11}$ The division of tasks among health professionals can help in the work process organization, but it can also lead to a process of fragmentation and segmentation of work, compromising teamwork's effectiveness.

However, knowledge institutionalization and its organization in the practical action in health would be through the core and field of competence and responsibility, being that the core contemplates the specific actions directed to the professional training, which confers the professional identity. However, the field of competence and responsibility is defined as imprecise spaces and limits, where each discipline and profession complements each other with a view to fulfilling their responsibilities in the health work process. ${ }^{30}$
It is worth noting that, according to the interviews, the practical performance of $\mathrm{FHS}$ professionals and the composition of knowledge are based more on the core than on the fields of competence and responsibility. This means that the professional's performance is restricted to their specific actuation core. An incipient and timid articulation process among the professionals only in certain situations in the FHS is evedenced.

In this way, professionals need to look beyond their own profession to share the goals with professionals from other backgrounds. ${ }^{27}$ This may contribute to the reconstruction of a shared path for the adequate care for the user, with participation of all the professionals in the care plan, indicating this as a powerful tool in health promotion, leading to care integrality.

The third thematic category, Teamwork at specific times, reveals that for the participants teamwork happens in specific times in the daily work of the FHT, as for example, in the actions taken with students, in groups with patients. This may reveal the perceptions that teamwork occurs at specific, predetermined times, in which everyone is gathered in the same place and involved in the same activity. However, it is not clear whether these respondents' perceptions on integrated work reflect an effective articulation, or merely a "grouping" of agents at specific times. It is also questioned if the subjects do not realize that teamwork must permeate the entire health work process, and not be configured as a tool for isolated and localized actions.

In this sense, other studies show that work in the FHP permeates the multidisciplinary logic but, depending on the level of interaction among the professionals, it may or may not guarantee interprofessionality and collective and integrated work. The mere fact of grouping professionals does not necessarily translate into collaborative practice. ${ }^{31-32}$

Collective activities with the participation of several professionals that make up the FHS do not always foster an integrative logic. It was evidenced that even these collective actions were based on the individualized perspective, with only the exposure of knowledge relative to the core of knowledge, and the non-interaction of knowledge, which does not favor the implementation of teamwork in the FHS. ${ }^{25}$ This was also evidenced in this research, showing that the participants identify teamwork as that which occurs in times when the professionals are physically together, regardless of whether there is interaction and knowledge exchange or not among them.

Thus, in order for the work to be minimally configured as collective, with a view to teamwork, how the professionals interact and relate to the work object is fundamental. If this space is used for the purpose of shared work, appropriating horizontal communication, with the sharing and articulation of actions, so this may boost teamwork. ${ }^{21,26-27}$

This study has as a limitation that the collect was performed in a single FHS team. However, the intent was to reveal the daily and dynamic work related to a team of professionals, because it was not intended to generalize the results, but to know the reality in more depth. It is believed that the found reality has many similarities with other PHC teams. 
As a recommendation, it is suggested to accomplish a research using the Critical Incident Technique to show real situations regarding teamwork, in the FHS, and to identify behaviors that favor and hinder such work modality in order to think about in-service strategies with a view to strengthening the positive aspects and overcoming the weaknesses.

\section{CONCLUSIONS}

The results show that professionals perceive teamwork as one that is anchored in mutual aid, collaboration and common goals. They reveal that the work in the FHS is carried out based on the specific attributions of each professional, and that this is configured as teamwork. However, the reports do not indicate articulation and effective integration among agents, knowledge and actions.

Through the speeches, it is observed that in practice the work follows the most individualized trend. This is clear in the interviews where the participants argue that when they are together in certain actions, at specific times in the FHS, this is characterized as teamwork. However, they do not mention whether there is an exchange of knowledge and integration.

Thus, these results indicate that the FHS professionals are unaware that the constituent elements of teamwork must permeate the whole work process in the FHT, that without the use of these elements, teamwork is not effective and may reinforce fragmented health care.

The results were displayed to the managers of the Family Health units of the three Sanitary Districts, in a meeting at the Municipal Health Department, in the city in focus. It is hoped to contribute through the reflection on the findings as flags to promote collective actions, more integrated and supportive. It is believed that studies of this nature may even favor future curricular changes in health courses, so that they may incorporate non-material aspects as being fundamental in the professional practice. This research also highlights the need for investment in the interprofessional collaboration in undergraduate and graduate courses and in in-service training/qualification.

\section{REFERENCES}

1. Giovanella L, Almeida PF. Comprehensive primary care and segmented health systems in South America. Cad Saúde Pública [Internet]. 2017; [cited 2018 Jul 10]; 33(Suppl 2):e00118816. Available from: http://www. scielo.br/pdf/csp/v33s2/1678-4464-csp-33-s2-e00118816.pdf. DOI: 10.1590/0102-311X00118816

2. López-Fernández LA, Hormazábal OS. Repensar la carta de Ottawa 30 años después. Gac Sanit [Internet]. 2017; [cited 2018 Jul 10]; 31(6):443-5. Available from: http://scielo.isciii.es/pdf/ gs/v31n6/0213-9111-gs-31-06-00443.pdf. DOI: http://dx.doi. org/10.1016/j.gaceta.2016.12.013

3. Pires-Alves FA, Cueto M. The Alma-Ata Decade: the crisis of development and international health. Ciênc Saúde Coletiva [Internet]. 2017; [cited 2018 Jul 10]; 22(7):2135-44. Available from: http://www. scielo.br/pdf/csc/v22n7/en_1413-8123-csc-22-07-2135.pdf. DOI: $10.1590 / 1413-81232017227.02032017$
4. Ministério da Saúde (BR). Gabinete do Ministro. Portaria №. 2.436 de 21 de setembro de 2017. Aprova a Política Nacional de Atenção Básica, estabelecendo a revisão de diretrizes para a organização da Atenção Básica, no âmbito do Sistema Único de Saúde (SUS) [Internet]. Brasília: Ministério da Saúde;2017 [cited 2018 Jan20]. Available from: http://bvsms. saude.gov.br/bvs/saudelegis/gm/2017/prt2436_22_09_2017.html

5. Bousquat A, Giovanella L, Campos EMS, Almeida PF, Martins CL, Mota PHS, et al. Primary health care and the coordination of care in health regions: managers' and users' perspective. Ciênc Saúde Coletiva [Internet]. 2017; [cited $2018 \mathrm{Jul} \mathrm{10];} \mathrm{22(4):1141-54.} \mathrm{Available} \mathrm{from:}$ http://www.scielo.br/pdf/csc/v22n4/en_1413-8123-csc-22-04-1141. pdf. DOI: $10.1590 / 1413-81232017224.28632016$

6. Forte ECN, Pires DEP. Nurses in basic care: between job satisfaction and dissatisfaction. Trab Educ Saúde [Internet]. 2017 Sep/Dec; [cited 2018 July 10]; 15(3):709-24. Available from: http://www.scielo.br/ pdf/tes/v15n3/1678-1007-tes-15-03-0709.pdf. DOI: https://dx.doi. org/10.1590/1981-7746-sol00083

7. Martins JS, Abreu SCC, Quevedo MP, Bourget MMM. Estudo comparativo entre Unidades de Saúde com e sem Estratégia Saúde da Família por meio do PCATool. Rev Bras Med Fam Comunidade. 2016;11(38):1-13. DOI: http://dx.doi.org/10.5712/rbmfc11(38)1252

8. Schimith MD, Brêtas ACP, Simon BS, Brum DJT, Alberti GF, Bidó $M L D$, et al. Precarization and fragmentation of work in the family health strategy: impacts in Santa Maria (RS). Trab Educ Saúde [Internet]. 2017 Jan/Apr; [cited 2018 Jul 10]; 15(1):163-82. Available from: http://dx.doi. org/10.1590/1981-7746-sol00038

9. Kahl C, Meirelles BHS, Lanzoni GMM, Koerich C, Cunha KS. Ações e interações na prática clínica do enfermeiro na atenção primária à saúde. Rev Esc Enferm USP [Internet] 2018; [cited 2018 Jul 10]; 52:e03327. Available from: http://www.scielo.br/pdf/reeusp/v52/00806234-reeusp-52-e03327.pdf_DOI: http://dx.doi.org/10.1590/S1980220X2017025503327

10. Pinto LF, Giovanella L. The Family Health Strategy: expanding access and reducing hospitalizations due to ambulatory care sensitive conditions (ACSC). Ciênc Saúde Coletiva [Internet]. 2018; [cited 2018 Jul 10] 23(6):1903-13. Available from: http://www.scielo.br/pdf/csc/v23n6/en 14138123-csc-23-06-1903.pdf. DOI: 10.1590/1413-81232018236.05592018

11. Peduzzi M. Multiprofessional healthcare team: concept and typology. Rev Saúde Pública [Internet]. 2001; [cited 2018 Jul 10]; 35(1):103-9. Available from: http://www.scielo.br/pdf/rsp/v35n1/4144.pdf. DOI: http:// dx.doi.org/10.1590/S0034-89102001000100016

12. Goulart BF, Camelo SHH, Simões ALA, Chaves LDP. Teamwork in a coronary care unit: facilitating and hindering aspects. Rev Esc Enferm USP [Internet]. 2016; [cited 2018 Jul 10]; 50(3):479-86. Available from: http://www.scielo.br/pdf/reeusp/v50n3/0080-6234-reeusp-50-03-0482. pdf_DOI: http://dx.doi.org/10.1590/S0080-623420160000400015

13. Heidemann ITSB, Cypriano CC, Gastaldo D, Jackson S, Rocha CG, Fagundes E. A comparative study of primary care health promotion practices in Florianópolis, Santa Catarina State, Brazil, and Toronto, Ontario, Canada. Cad Saúde Pública [Internet]. 2018; [cited $2018 \mathrm{Ju}$ 10]; 34(4):e00214516. Available from: http://www.scielo.br/pdf/csp/ v34n4/1678-4464-csp-34-04-e00214516.pdf.DOI: 10.1590/0102$311 \times 00214516$

14. Selleck CS, Fifolt M, Burkart H, Frank JS, Curry WA, Hites LS. Providing primary care using an interprofissional collaborative practice model: what clinicians have learned. J Prof Nurs [Internet].2017 Nov/Dec; [cited 2018 Jul 10]; 33(6):410-6. Available from: http://dx.doi.org/10.1016/j. profnurs.2016.11.004

15. Arruda LS, Moreira COF. Interprofessional collaboration: a case study regarding the professionals of the Care Center for Elderly, Rio de Janeiro State University (NAI/UERJ), Brazil. Interface (Botucatu) [Internet]. 2018; [cited 2018 Jul 10]; 22(64):199-210. Available from: http://www. scielo.br/pdf/icse/v22n64/1807-5762-icse-1807-576220160613.pdf DOI: $10.1590 / 1807-57622016.0613$

16. Littike D, Sodré F. The art of improvisation: the working process of administrators at a Federal University Hospital. Ciênc Saúde Coletiva [Internet]. 2015; [cited 2018 Jul 10]; 20(10):3051-62. Available from: http://www.scielo.br/pdf/csc/v20n10/en_1413-8123-csc-20-10-3051. pdf. DOI: $10.1590 / 1413-812320152010.00042015$ 
17. Silva JAM, Peduzzi M, Orchad C, Leonello VM. Interprofessional education and collaborative practice in Primary Health Care. Rev Esc Enferm USP [Internet]. 2015; [cited $2018 \mathrm{Jul}$ 10]; 49(no.spe 2):15-23. Available from: http://www.scielo.br/pdf/reeusp/v49nspe2/en_1980-220X-reeusp-49spe2-0016.pdf_DOI: 10.1590/S0080-623420150000800003

18. Tavares MFL, Rocha RM, Bittar CML, Petersen CB, Andrade M. Health promotion in professional education: challenges in Health and the need to achieve in other sectors. Ciênc Saúde Coletiva [Internet]. 2016; [cited 2018 Jul 10]; 21(6):1799-808. Available from: http://www.scielo.br/pdf/ csc/v21n6/en 1413-8123-csc-21-06-1799.pdf. DOI: 10.1590/141381232015216.07622016

19. Agreli HF, Peduzzi M, Silva MC. Patient centred care in interprofessional collaborative practice. Interface (Botucatu) [Internet]. 2016; [cited 2018 Jul 10]; 20(59):905-16. Available from: http://www.scielo.br/ pdf/icse/v20n59/en_1807-5762-icse-1807-576220150511.pdf.DOI: 10.1590/1807-57622015.0511

20. Souza GC, Peduzzi M, Silva JAM, Carvalho BG. Teamwork in nursing: restricted to nursing professionals or an interprofessional collaboration? Rev Esc Enferm USP [Internet]. 2016; [cited 2018 Jul 10]; 50(4):640-7. Available from:http://www.scielo.br/pdf/reeusp/v50n4/0080-6234-reeusp-50-04-0642. pdf_.DOI: http://dx.doi.org/10.1590/S0080-623420160000500015

21. Gonçalves RBM. Práticas de saúde: processos de trabalho e necessidades. São Paulo: CEFOR; 1992.

22. Ministério do Planejamento, Orçamento e Gestão (BR). Instituto Brasileiro de Geografia e Estatística (IBGE). Brazil. Minas Gerais, Cidades. Uberaba [Internet]. Rio de Janeiro: IBGE; 2010 [cited 2019 May 21]. Available from: https://cidades.ibge.gov.br/brasil/mg/uberaba

23. Bardin L. Análise de conteúdo. Lisboa: Edições 70; 2011

24. Ministério da Saúde (BR). Conselho Nacional de Saúde. Resolução №. 466 de 12 de dezembro de 2012 [Internet]. Brasília: Ministério da Saúde; 2012 [cited 2018 Jul 10]. Available from: http://conselho.saude. gov.br/resolucoes/2012/Reso466.pdf

25. Farias DN, Ribeiro KSQS, Anjos UU, Brito GEG. Interdiciplinario e interprofesionalidad en la estrategia salud de la família. Trab Educ Saúde [Internet]. $2018 \mathrm{Jan} / \mathrm{Apr}$; [cited $2018 \mathrm{Jul}$ 10]; 16(1):141-62. Available from: http://www.scielo.br/pdf/tes/v16n1/1678-1007-tes-1981-7746sol00098.pdf_DOI: http://dx.doi.org/10.1590/1981-7746-sol00098
26. Mclnnes S, Peters K, Bonney A, Halcomb E. An integrative review of facilitators and barriers influencing collaboration and teamwork between general practitioners and nurses working in general practice. J Adv Nurs [Internet]. 2015 Sep; [cited 2018 Jul 10]; 71(9):1973-85. Available from: https://doi.org/10.1111/jan.12647

27. van Dongen JJ, Lenzen SA, van Bokhoven MA, Daniëls R, van der Weijden T, Beurskens A. Interprofessional collaboration regarding patients' care plans in primary care: a focus group study into influentia factors. BMC Fam Pract [Internet]. 2016 May 28; [cited 2018 Jul 10]; 17:58. Available from: https://www.ncbi.nlm.nih.gov/pubmed/27233362. DOI: 10.1186/s12875-016-0456-5

28. Fiscella K, Mauksch L, Bodenheimer T, Salas E. Improving Care Teams' Functioning: Recommendations from Team Science. Jt Comm J Qual Patient Saf [Internet]. 2017 Jul; [cited 2018 Jul 10]; 43(7):361-8. Available from: http://dx.doi.org/10.1016/j.jcjq.2017.03.009

29. Gordo F, Abella A. Intensive care unit without walls: Seeking patient safety by improving the efficiency of the system. Med Intensiva [Internet] 2014; [cited 2018 Jul 10]; 38(7):438-43. Available from: http://www. elsevier.es/en/linksolver/ft/pii/S0210-5691(14)00041-2. DOI: http:// dx.doi.org/10.1016/j.medin.2014.02.001

30. Campos GWS. Public health and collective health: field and core area for knowledge and practice. Ciênc Saúde Coletiva [Internet]. 2000; [cited 2018 Jul 10]; 5(2):219-30. Available from: http://www.scielo.br/pdf/csc/ v5n2/7093.pdf

31. Jacowski M, Budal AMB, Lemos DS, Ditterich RG, Buffon MCM Mazza VA. Teamwork: the professionals' perception of family health strategy. Rev Baiana Enferm [Internet]. 2016 Apr/Jun; [cited 2018 Jul 10]; 30(2):1-9. Available from: https://portalseer.ufba.br/index. php/enfermagem/article/view/15145/pdf_41. DOI: 10.18471/rbe. v30i2.15145

32. Matuda CG, Pinto NRS, Martins CL, Frazão P. Interprofessional collaboration in the Family Health Strategy: implications for the provision of care and work management. Ciênc Saúde Coletiva [Internet]. 2015 [cited $2018 \mathrm{Jul}$ 10]; 20(8):2511-21. Available from: http://www.scielo. br/pdf/csc/v20n8/1413-8123-csc-20-08-2511.pdf. DOI: 10.1590/141381232015208.11652014 